\title{
PENERAPAN MODEL PEMBELAJARAN TALKING STICK BERBANTUAN MEDIA FLASH CARD UNTUK MENINGKATKAN KEMAMPUAN BERBICARA
}

\author{
Ida Ayu Sugiantiningsih ${ }^{1}$, Putu Aditya Antara² \\ 1,2 Jurusan Pendidikan Guru Pendidikan Anak Usia Dini, \\ Fakultas IImu Pendidikan \\ Universitas Pendidikan Ganesha \\ Singaraja, Indonesia \\ e-mail: dayuugi48@gmail.com¹,putu.aditya.antara@gmail.com²
}

\begin{abstract}
Abstrak
Penelitian ini bertujuan untuk mengetahui peningkatan terhadap kemampuan berbicara setelah adanya penerapan model pembelajaran talking stick berbantuan media flash card untuk meningkatkan kemampuan berbicara pada anak kelompok B2 TK Kartika VII-3 Singaraja tahun ajaran 2018/2019. Penelitian ini merupakan Penelitian Tindakan Kelas (PTK) yang telah dilaksanakan dengan 2 siklus penelitian. Subjek penelitian adalah anak kelompok B2 TK Kartika VII-3 Singaraja yang berjumlah 18 orang anak, terdiri dari 10 anak laki-laki dan 8 anak perempuan. Metode pengumpulan data yang digunakan dalam penelitian ini adalah metode observasi dan dokumentasi foto dan video. Data dari hasil penelitian dianalisis menggunakan metode analisis statistik deskriptif dan metode analisis deskriptif kuantitatif. Hasil analisis data menunjukkan bahwa terjadi peningkatan kemampuan berbicara setelah adanya penerapan model pembelajaran talking stick berbantuan media flash card, hal ini dapat dilihat dari peningkatan angka rata-rata persentase pada siklus I sebesar $67,08 \%$ dengan kriteria sedang mengalami peningkatan pada siklus II menjadi $81,91 \%$ yang berada pada kriteria tinggi. Dengan demikian terjadi peningkatan angka rata-rata persentase dari siklus I ke siklus II sebesar $14,83 \%$. Dapat disimpulkan bahwa penerapan model pembelajaran talking stick berbantuan media flash card dapat meningkatkan kemampuan berbicara pada anak kelompok B2 TK Kartika VII3 Singaraja tahun ajaran 2018/2019.
\end{abstract}

Kata-kata kunci: model pembelajaran talking stick, flash card, kemampuan berbicara

\begin{abstract}
This study aims to determine the improvement of speaking ability after the application of talking stick learning model assisted with flash card as media to improve the ability to speak to the group of children of B2 TK Kartika VII-3 Singaraja in 2018/2019 academic year. This research is a Class Action Research (CAR) which has been carried out with 2 research cycles. The subject of the study was the group of children of the TK Kartika VII-3 Singaraja B2, amounting to 18 children, consisting of 10 boys and 8 girls. The data collection methods used in this study were photos and videos observation and documentation methods. The data from research results were analyzed using descriptive statistical analysis methods and quantitative descriptive analysis methods. The results of data analysis showed that there was an enhancement of speaking ability after the implementation of cooperative learning model talking stick assisted by flash card, this can be seen from the enhancement in the average of percentage in the first cycle of $67.08 \%$ with the criteria being increased in the second cycle to $81.91 \%$ who are in high criteria. Therefore an increase in the average number of percentages from cycle I to cycle II is $14.83 \%$. It can be concluded that the application of talking stick learning model assisted by flash card media can improve the ability to speak to the group of children of B2 TK Kartika VII-3 Singaraja in 2018/2019 academic year.
\end{abstract}

Key words: talking stick learning model, flash card, speaking ability

Jurnal Ilmiah Pendidikan Profesi Guru | 298 


\section{Pendahuluan}

Anak usia dini sering disebut dengan masa golden age, dimana perkembangan dan pertumbuhan anak di usia ini memerlukan perhatian ekstra dari orang dewasa di sekitarnya. Tahun-tahun pertama kehidupan anak adalah masa sangat penting karena merupakan dasar perkembangan atau penentu perkembangan selanjutnya. Tentu tidak berarti tahap usia berikutnya tidaklah penting, namun dapat dikatakan pada masa tersebut merupakan pondasi bagi perkembangan individu. Sikap, kebiasaan, dan pola perilaku yang dibentuk di awal sangat menentukan seberapa jauh anak tersebut berhasil menyesuaikan diri dalam kehidupan yang akan datang.

Anak disebut usia dini dari rentang usia 0 sampai 6 tahun, disaat inilah orang tua harus menanamkan hal-hal baik pada seorang anak. Sikap yang dimiliki akan cenderung menetap sepanjang hidupnya. Implikasinya adalah kita dapat memprediksi bagaimana perkembangan seorang anak di masa yang akan datang, selain itu anak usia dini juga mengalami pertumbuhan dan perkembangan baik fisik maupun mental yang sangat pesat. Sel-sel tubuh anak tumbuh dan berkembang amat cepat. Selain pertumbuhan dan perkembangan fisik dan motorik, perkembangan moral (termasuk kepribadian, watak, dan akhlak), sosial, emosional, intelektual, dan bahasa juga berlangsung amat pesat.

Dengan adanya pendidikan anak usia dini (PAUD) yang bertujuan membimbing dan mengembangkan potensi setiap anak agar dapat berkembang secara optimal sesuai tipe kecerdasannya. Maka dari itu guru harus memahami kebutuhan khusus dan kebutuhan individual anak. Oleh karenanya PAUD diarahkan untuk memfasilitasi setiap anak dengan lingkungan belajar dan bimbingan belajar yang tepat agar anak dapat berkembang sesuai dengan tahapan perkembangan anak usia dini yang melibatkan seluruh aspek perkembangan didalamnya yaitu nilai agama dan moral, sosial emosional, kognitif, fisik motorik, dan bahasa.

Perkembangan bahasa yang meliputi menerima dan mengungkapkan bahasa pada anak dapat dilihat dari bagaimana kemampuannnya dalam berbicara, dimana kemampuan berbicara anak usia dini merupakan penentu bagaimana mereka akan mengenal dunia luar, karena dengan berkembangnya kemampuan berbicara berkembang pula kemampuan berkomunikasi yang nantinya akan menentukan kemampuannya bergaul (social skill). Belajar berbicara dapat dilakukan anak dengan bantuan dari orang dewasa melalui percakapan. Dengan bercakapcakap, anak akan menemukan pengalaman dan meningkatkan pengetahuannya dan mengembangkan bahasanya. Hal ini selaras dengan karakteristik umum kemampuan bahasa anak tersebut. Menurut Dhieni (2007) "kemampuan berbicara anak dapat dikatakan berkembang dengan baik ketika anak dapat melaksanakan tiga perintah lisan secara berurutan dengan benar, mendengarkan dan bercerita kembali cerita sederhana dengan urutan yang mudah di pahami, menyebutkan nama, jenis kelamin, dan umurnya". Jadi kemampuan berbicara tersebut dapat berkembang dapat dilakukan anak dengan bantuan dari orang dewasa melalui percakapan. Dengan bercakap-cakap, anak akan menemukan pengalaman dan meningkatkan pengetahuannya dan mengembangkan bahasanya.

Kemampuan berbicara anak usia dini memang salah satu aspek yang penting pada anak yang perlu kita perhatikan. Tidak ada salahnya meluangkan waktu lebih untuk melatih anak berbicara, karena dengan kemampuan berbicara yang baik dan dikuasai pada usia dini anak akan dapat dengan mudah merespon stimulus dari lingkungan sekitarnya yang nantinya akan mempengaruhi kecerdasan dari si anak itu sendiri.

Dalam proses pembelajaran, khususnya kemampuan berbicara anak banyak dijumpai permasalahannya yaitu kurangnya kesempatan pada anak dapat berbicara secara keseluruhan atau merata, tindakan disiplin berlebihan yang membatasi anak mengungkapkan pendapatnya serta kurangnya guru dalam memberikan stimulus-stimulus yang merangsang agar anak mau berbicara. Di dalam melatih kemampuan berbicara anak, guru seringkali menggunakan strategi pembelajaran yang monoton, sehingga membuat anak tidak menghiraukan penjelasan gurunya dan sibuk sendiri dengan aktivitas mereka. Pada saat melakukan observasi langsung, proses pembelajaran dalam mengembangkan kemampuan bahasa khususnya dalam kemampuan 
berbicara pada anak di TK Kartika VII-3 Singaraja di peroleh beberapa informasi yaitu; (1) di TK Kartika VII-3 Singaraja memberi tindak disiplin yang cukup berlebihan pada anak saat melakukan percakapan bersama sehingga anak terbatas dalam mengungkapkan pendapatnya, (2) setengah anak tidak fokus dalam mengikuti proses pembelajaran karena kurang kondusifnya situasi kelas, (3) perkembangan kemampuan berbicara anak belum distimulasi dengan optimal, dan (4) Guru belum pernah menggunakan model pembelajaran talking stick berbantuan media flash card di TK VII-3 Singaraja.

Terkait dengan permasalahan tersebut, guru harus merancang pembelajaran yang menyenangkan bagi anak dan membuat media pembelajaran yang menarik untuk diimplementasikan pada saat proses pembelajaran. Agar dapat mengoptimalkan proses pembelajaran, guru seharusnya memilih model pembelajaran yang sesuai dengan tujuan dan materi pengajaran. Model pembelajaran yang diterapkan harus mampu meningkatkan keterlibatan terhadap anak, metode-metode yang masih menampilkan guru sebagai tokoh sentral di muka kelas (teacher center) lebih minim untuk dilakukan, selain itu pembelajaran tidak harus berasal dari pendidik menuju ke anak. Penggunaan model pembelajaran yang kurang tepat dapat menimbulkan kebosanan, sulit dipahami anak dan cenderung monoton/membosankan, sehingga anak kurang fokus dan termotivasi untuk belajar hingga berdampak pada kemampuan perkembangan bahasa anak yang berkembang kurang optimal.

Mengatasi permasalahan tersebut, diupayakan dengan adanya penerapan model pembelajaran praktis yang mudah diterapkan guru serta menyenangkan bagi anak. Salah satu upaya untuk meningkatkan kemampuan berbicara anak adalah dengan menerapkan model pembelajaran talking stick. Model pembelajaran talking stick merupakan sebuah varian model pembelajaran yang akan membuat kegiatan pembelajaran menarik dan menyenangkan melalui kegiatan bermain, serta dapat melatih mental dan membuat anak aktif saat pembelajaran.

Adapun kelebihan model pembelajaran talking stick. Menurut Suprijono (dalam Jasmi, 2014) menyatakan bahwa, kelebihan model talking stick yaitu menguji kesiapan siswa, melatih siswa membaca dan memahami materi dengan cepat, memacu siswa agar lebih giat belajar, dan siswa berani mengemukakan pendapat". Sejalan dengan pendapat tersebut, menurut Kurnasih dan Sani (2015:83), "kelebihan dari model pembelajaran talking stick adalah menguji kesiapan anak dalam penguasaan materi pelajaran, melatih membaca dan memahami dengan cepat materi yang telah disampaikan, serta agar lebih giat belajar karena anak tidak tahu tongkat akan sampai pada gilirannya". Jadi model pembelajaran talking stick mengajak anak belajar melalui kegiatan bermain disamping itu dapat melatih anak untuk memahami materi dengan cepat serta melatih mentalnya menunjukkan sikap berani dalam mengungkapkan pendapatnya.

Demi kelancaran proses pelaksanaan penelitian, maka perlu diketahui dan dipahami terlebih dahulu sintaks model pembelajaran talking stick. Menurut Uno (2012:124) mengemukakan sintaks model pembelajaran talking stick yaitu (1) guru menyiapkan tongkat; (2) guru menyiapkan dan menjelaskan materi; (3) guru mengambil tongkat dan jika tongkat berhenti, maka guru memberikan siswa tugas/pertanyaan; (4) guru memberikan kesimpulan; (5) guru mengevaluasi pembelajaran; (6) guru menutup pembelajaran.

Selain pemilihan model pembelajaran, dalam proses pembelajaran media memegang peranan penting dalam pembelajaran anak usia dini. Media flash card sebagai media pendukung dalam proses pembelajaran. Menurut Sutan (2004:9) menyatakan bahwa, "media flashcard merupakan media pengajaraan dengan metode membaca gambar dengan menggunakan kartukartu yang berisi tanda, teks atau simbol yang berhubungan dengan gambar itu. Selain itu menurut Yulianty (2014:48) menyatakan bahwa "media flash card adalah media yang diperuntukan untuk anak dalam merangsang kemampuan berbicara anak". Jadi dapat disimpulkan media flash card merupakan salah satu media pendidikan edukatif yang berisikan gambar-gambar serta kata yang disesuaikan dengan tema pembelajaran yang diberikan, flash card selain sebagai sarana permainan juga berfungsi sebagai media belajar yang efektif bagi anak terutama dalam hal mengingat dan menghafal.

Berdasarkan uraian yang telah dipaparkan sebelumnya, maka tujuan penelitian yang dilakukan dengan penerapan model pembelajaran talking stick berbantuan media flashcard 
Jurnal IImiah Pendidikan Profesi Guru Vol. 2 No. 3, Oktober 2019

P-ISSN : 2621-5713, E-ISSN : 2621-5705

untuk meningkatkan kemampuan berbicara pada anak kelompok B2 TK Kartika VII-3 Singaraja Tahun Ajaran 2018/2019.

\section{Metode}

Penelitian ini dilakukan pada anak kelompok B2, berjumlah 18 anak terdiri dari 10 anak lakilaki dan 8 anak perempuan yang bertempat di TK Kartika VII-3 Singaraja. Jenis penelitian yang dilakukan ini adalah Penelitian Tindakan Kelas (PTK). Penelitian ini juga disebut sebagai Classroom Action Research, yang kegiatan memecahkan masalahnya dilaksanakan melalui penerapan di dalam kelas. Agung (2010:3) menyatakan bahwa: Penelitian Tindakan Kelas (PTK) adalah penelitian yang bersifat aplikasi (terapan), terbatas, segera, dan hasilnya untuk memperbaiki dan menyempurnakan proses atau program (program pembelajaran) yang sedang berjalan.

Langkah-langkah penelitian dalam masing-masing tindakan terjadi secara berulang-ulang yang akhirnya menghasilkan beberapa tindakan dalam penelitian tindakan kelas. Pada penelitian ini menerapkan desain model PTK dari Kemmis dan Mc Taggart, dimana model desain ini menggunakan empat komponen penelitian dalam setiap langkah yaitu (1) perencanaan, (2) tindakan, (3) observasi, dan (4) refleksi. Tahapan dalam setiap siklus penelitian dapat dilihat pada gambar 1 di bawah ini.

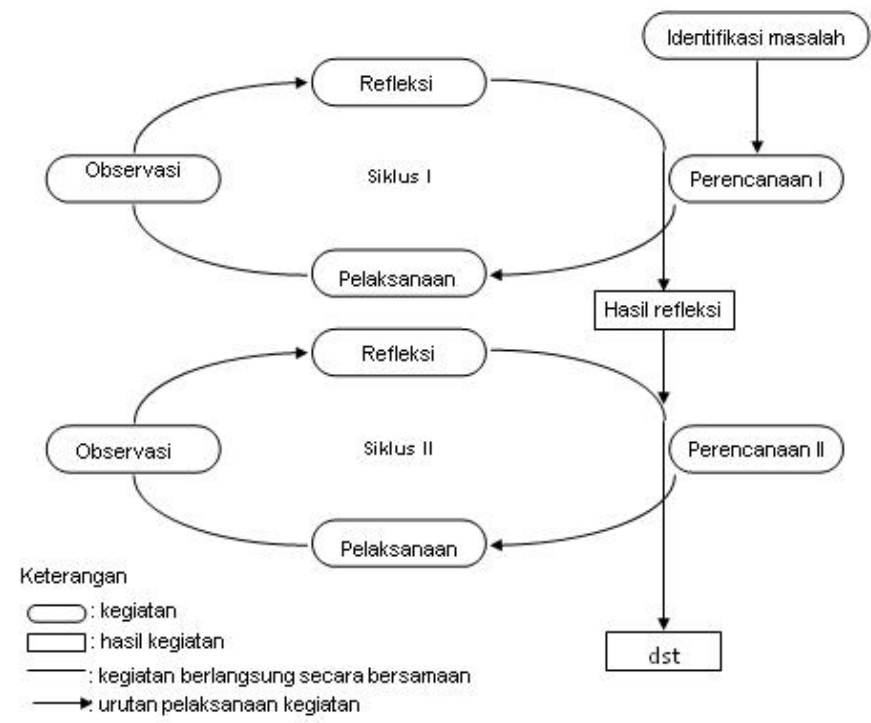

(Arikunto dalam saputri, 2015:34)

Gambar 1. Gambar Model Penelitian Tindakan Kelas

Dalam mengumpulkan data penelitian ini menggunakan metode observasi dan dokumentasi foto dan video. menurut Ridwan (2004:104) "teknik observasi merupakan teknik pengumpulan data, dimana peneliti melakukan pengamatan secara langsung ke objek penelitian untuk melihat dari dekat kegiatan yang dilakukan", dan pendapat lain menurut Sudijono (2011:84) mengemukakan bahwa "observasi atau pengamatan sebagai alat penilaian banyak digunakan untuk mengukur tingkah laku individu atau proses terjadinya suatu kegiatan yang dapat diamati, baik dalam situasi yang sebenarnya atau juga dalam situasi buatan". Jadi, metode observasi adalah cara memperoleh data dengan pengamatan pada objek tertentu. Penggunaan portofolio dalam metode pengumpulan data ini diperuntukkan mencatat penilaian hasil karya anak sehubungan dengan tugas yang telah diberikan. Sedangkan teknik pengumpulan data dengan dokumentasi foto dan video dilakukan untuk merekam data visual tentang kegiatan pembelajaran atau hasil pembelajaran

Adapun Instrumen pengumpulan data yang digunakan dalam penelitian ini adalah menggunakan lembar observasi. Lembar observasi adalah alat yang digunakan untuk acuan 
pengamatan, untuk mengetahui sejauh mana peningkatan yang terjadi pada kemampuan berbicara anak. Setiap kegiatan yang diobservasi dikategorikan ke dalam kualitas yang sesuai yaitu anak belum berkembang dengan skor 1, anak mulai berkembang dengan skor 2, anak berkembang sesuai harapan dengan skor 3, anak berkembang sangat baik dengan skor 4 . Lembar yang digunakan dalam menilai kemampuan tiap anak adalah dengan rubrik penilaian kemampuan berbicara yang dapat disajikan dalam bentuk tabel rubrik seperti yang ada di bawah ini.

Tabel 1. Tabel Rubrik Penilaian Kemampuan Berbicara Anak

\begin{tabular}{|c|c|c|c|}
\hline No & Indikator & Deskriptor & Skor \\
\hline 1. & $\begin{array}{l}\text { Ketepatan } \\
\text { Ucapan }\end{array}$ & $\begin{array}{l}\text { Anak tidak mau berkomunikasi meski sudah di } \\
\text { arahkan guru } \\
\text { Anak mau berkomunikasi namun memberi } \\
\text { jawaban singkat (S P / O / K) } \\
\text { Anak mau berkomunikasi menggunakan } \\
\text { struktur kalimat lengkap yaitu SPOK } \\
\text { Anak mau berkomunikasi menggunakan } \\
\text { struktur kalimat lengkap dan majemuk / } \\
\text { pengembangan (SPOK - SPOK) }\end{array}$ & $\begin{array}{l}1 \\
2 \\
3 \\
4\end{array}$ \\
\hline 2. & Pilihan Kata & $\begin{array}{l}\text { Anak cenderung diam } \\
\text { Anak mau memberi jawaban singkat ( } 1 \text { kata) } \\
\text { Anak mau berkomunikasi hanya } 1 \text { kalimat }(3- \\
4 \text { kata) } \\
\text { Anak mau berkomunikasi dengan lebih dari } 1 \\
\text { kalimat ( } 5 \text { - } 6 \text { kata) atau lebih }\end{array}$ & $\begin{array}{l}1 \\
2 \\
3 \\
4\end{array}$ \\
\hline 3. & $\begin{array}{l}\text { Kenyaringan } \\
\text { suara dan } \\
\text { kelancaran } \\
\text { dalam } \\
\text { berbicara }\end{array}$ & $\begin{array}{l}\text { Anak berbicara tidak jelas } \\
\text { Anak mampu berbicara namun ada beberapa } \\
\text { kata diucapkan kurang jelas } \\
\text { Anak mampu berbicara dengan jelas } \\
\text { Anak mampu berbicara dengan jelas dan } \\
\text { intonasi tepat }\end{array}$ & $\begin{array}{l}1 \\
2 \\
3 \\
4\end{array}$ \\
\hline
\end{tabular}

Setelah data yang diperlukan dalam penelitian ini terkumpul, maka dilakukan analisis data dengan menggunakan metode analisis statistik deskriptif dan metode analisis deskriptif kuantitatif. Menurut Agung (2012:67) menyatakan "metode analisis statistik deskriptif adalah cara pengolahan data yang dilakukan dengan jalan menerapkan rumus-rumus statistik deskriptif seperti tabel distribusi frekuensi, grafik, angka rata-rata (mean), median (Md), dan modus (Mo) untuk menggambarkan keadaan objek/variabel sehingga diperoleh kesimpulan umum".

Dalam penerapan metode analisis statistik deskriptif ini, data yang diperoleh dari hasil penelitian dianalisis dan disajikan ke dalam: (a) tabel distribusi frekuensi, (b) menghitung modus (Mo), (c) menghitung median (Md), (d) menghitung mean atau angka rata-rata (M), dan (e) menyajikan data ke dalam grafik polygon.

Selanjutnya untuk memperoleh kesimpulan pengumpulan hasil data, penelitian ini menggunakan metode analisis deskriptif kuantitatif dalam bentuk persentase. Menurut Agung (2010:9) menyatakan "metode analisis deskriptif kuantitatif adalah suatu cara pengolahan data yang dilakukan dengan jalan menyusun secara sistematis dalam bentuk angka-angka dan atau persentase mengenai keadaan suatu objek yang diteliti sehingga diperoleh kesimpulan umum". Metode analisis deskriptif kuantitatif ini digunakan untuk menentukan tingkat tinggi rendahnya 
kemampuan berbicara dengan menerapkan model pembelajaran talking stick berbantuan media flash card yang dikonversikan ke dalam Pedoman Acuan Penilaian (PAP) skala lima.

Menganalisis data menggunakan metode analisis deskriptif kuantitatif untuk mencari persentase tingkat kemampuan berbicara digunakan rumus $\mathrm{M} \%$ atau angka rata-rata persen sebagai berikut.

$\mathrm{M}(\%)=\left[\frac{M}{S M I}\right] \times 100 \%$

Keterangan:

$\mathrm{M}(\%) \quad=$ Rata-rata Persen

$\mathrm{M} \quad=$ Skor Mean

SMI = Skor Maksimal Ideal

Hasil dari angka rata-rata persen (M\%) kemudian dibandingkan ke dalam PAP skala lima untuk dapat menentukan tingkat kemampuan berbicara. Pedoman dari PAP skala lima tentang tingkatan kemampuan berbicara seperti pada table di bawah ini.

Tabel 2. Tabel Pedoman PAP Skala Lima Tentang Tingkatan Kemampuan Berbicara

\begin{tabular}{cc}
\hline Presentase $(\%)$ & Kriteria Kemampuan Berbicara \\
\hline $90-100$ & Sangat Tinggi \\
$80-89$ & Tinggi \\
$65-79$ & Sedang \\
$55-64$ & Rendah \\
$0-54$ & Sangat Rendah \\
\hline
\end{tabular}

(Agung, 2010:10)

Sebagai suatu tolak ukur dalam penelitian ini akan ditetapkan kriteria keberhasilan penelitian. Penelitian ini dinyatakan berhasil jika terjadi perubahan positif skor rata-rata dari siklus I ke siklus berikutnya dan jika dikonversikan pada pedoman PAP Skala lima tentang tingkat kemampuan berbicara berada pada rentang 80-89 dengan kriteria tinggi

\section{Hasil dan Pembahasan}

Hasil

Penelitian tindakan kelas ini dilaksanakan di TK Kartika VII-3 Singaraja dan dilakukan dari bulan September-Oktober 2018. Penelitian ini menggunakan penelitian tindakan bersiklus yakni pada siklus I dilaksanakan dengan 4 kali pertemuan. Pelaksanaan siklus I ini dilaksanakan berdasarkan rencana pelaksanaan pembelajaran yang telah dirancang sebelumnya. Mulai dari membuat Rencana Pelaksanaan Pembelajaran Mingguan (RPPM) serta Rencana Pelaksanaan Pembelajaran Harian (RPPH) yang telah dikonsultasikan dan disepakati bersama guru di sekolah.

Dari hasil analisis data statistik deskriptif pada siklus I diperoleh modus sebesar 7, median sebesar 8, mean sebesar 8,05 untuk data kemampuan berbicara anak.

Berikut ini adalah grafik polygon dari hasil data yang dicapai pada siklus I. 


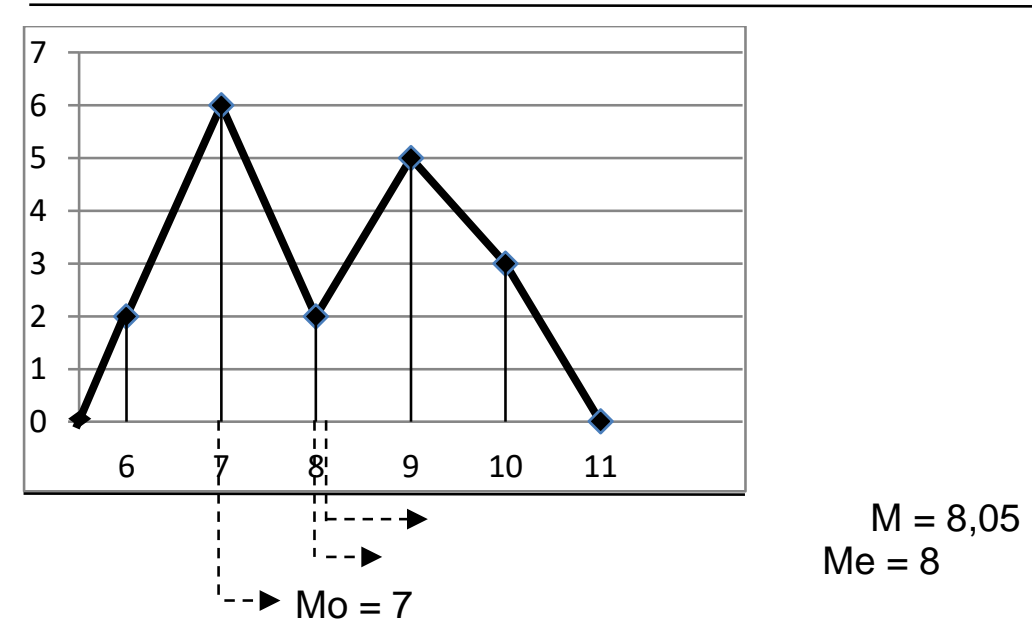

Gambar 2. Gambar Grafik Polygon Kemampuan Berbicara pada siklus I

Berdasarkan hasil analisis data yang disajikan dalam grafik polygon menunjukkan bahwa Modus < Median < Mean $(7<8<8,05)$, sehingga dapat dikatakan bahwa sebaran data-data kemampuan berbicara pada siklus I merupakan kurva juling positif. Dengan demikian dapat diinterpretasikan bahwa skor kemampuan berbicara pada anak kelompok B2 di TK Kartika VII-3 Singaraja cenderung sedang.

Selanjutnya untuk menentukan tingkat penguasaan kemampuan berbicara dapat dihitung menggunakan rumus $\mathrm{M} \%$, hasil dari $\mathrm{M} \%$ tersebut dibandingkan dengan kriteria PAP skala lima. Diperoleh hasil M\% $=67,08 \%$, apabila dikonversikan ke dalam PAP skala lima seperti yang terlihat pada tabel 2 , maka M\% berada pada tingkat penguasaan $65 \%-79 \%$ yang berarti kemampuan berbicara anak pada siklus I berada pada kriteria sedang.

Berdasarkan hasil pengamatan dan temuan selama pelaksanaan tindakan pada siklus I terdapat beberapa masalah yang menyebabkan kemampuan berbicara anak masih berada pada kriteria sedang, sehingga dari hasil pengamatan kemampuan berbicara anak masih perlu untuk ditingkatkan pada siklus selanjutnya. Adapun kendala-kendala serta kekurangan saat pelaksanaan tindakan siklus I yaitu: (a) anak kurang paham dan kurang bekerjasama dalam menerapkan model pembelajaran talking stick, (b) media flash card terlalu kecil sehingga gambar dapat dilihat hanya oleh anak yang mendapat giliran, dan (c) saat menceritakan gambar dalam flash card ada beberapa anak yang masih bingung dan malu mengungkapkan pendapatnya.

Untuk mengatasi kendala-kendala tersebut, dalam melaksanakan siklus II akan dilakukan hal-hal sebagai berikut. (a) akan lebih memperinci dalam menjelaskan setiap langkah dalam penerapan model pembelajaran talking stick disertai dengan contoh kegiatan langsung, (b) Menyiapkan media flash card yang lebih besar sehingga dapat dilihat oleh semua anak dalam proses pembelajarannya, dan (c) memberikan arahan dan bimbingan secara kelompok maupun individu yang memiliki kendala dalam menceritakan gambar dalam flash card ataupun bekerjasama dalam kelompok dengan cara yang menyenangkan, misalnya diberikan kegiatan belajar melalui bermain tebak kata/kalimat/gerak.

Berdasarkan hasil refleksi tersebut, maka penelitian tindakan kelas ini perlu dilanjutkan ke siklus II untuk peningkatan dan penyempurnaan kemampuan berbicara pada anak.

Kegiatan pada siklus II dilaksanakan dengan 4 kali pertemuan. Pelaksanaan siklus II ini dilaksanakan berdasarkan hasil dari refleksi sikus I, membuat Rencana Pelaksanaan Pembelajaran Mingguan (RPPM) serta Rencana Pelaksanaan Pembelajaran Harian (RPPH) yang telah dikonsultasikan dan disepakati bersama guru di sekolah.

Dari hasil analisis data statistik deskriptif pada siklus II diperoleh mean sebesar 9,83, median sebesar 10, modus sebesar 11 untuk data kemampuan berbicara anak. Berikut ini adalah grafik polygon dari hasil data yang dicapai pada siklus II. 


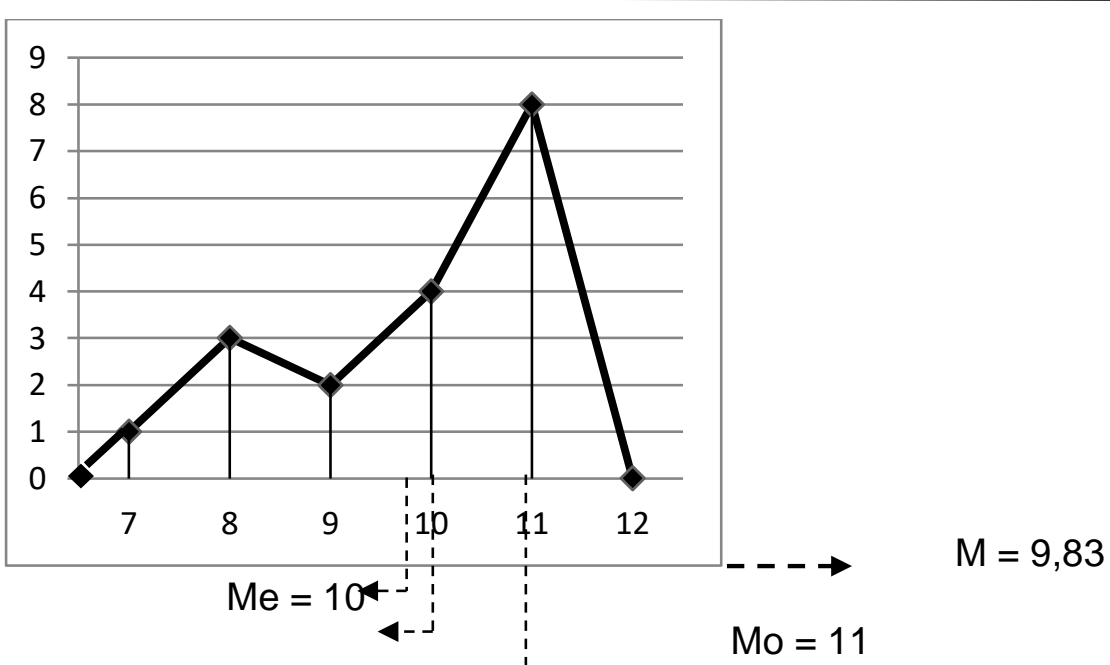

Gambar 3. Gambar Ğrafik Polygon Kemampuan Berbicara pada siklus II

Berdasarkan hasil analisis data yang disajikan dalạm grafik polygon menunjukkan bahwa Mean < Median < Modus $(9,83<10<11)$, sehinggaldapat dikatakan bahwa sebaran data-data kemampuan berbicara pada siklus II merupakạn kurva juling negatif. Dengan demikian dapat diinterpretasikan bahwa skor kemampuan berbicara pada anak kelompok B2 di TK Kartika VII-3 Singaraja cenderung tinggi.

Selanjutnya untuk menentukan tingkat penguasaan kemampuan berbicara dapat dihitung menggunakan rumus $\mathrm{M} \%$, hasil dari $\mathrm{M} \%$ tersebut dibandingkan dengan kriteria PAP skala lima. Diperoleh hasil $\mathrm{M} \%=81,91 \%$, apabila dikonversikan ke dalam PAP skala lima seperti yang terlihat pada tabel 2 , maka $\mathrm{M} \%$ berada pada tingkat penguasaan $80 \%-89 \%$ yang berarti bahwa kemampuan berbicara anak pada siklus II berada pada kriteria tinggi.

Sesuai keseluruhan data yang telah didapat dalam penelitian ini, adapun data rekapitulasi kemampuan berbicara anak pada siklus I dan siklus II dapat dijelaskan melalui grafik sebagai berikut.

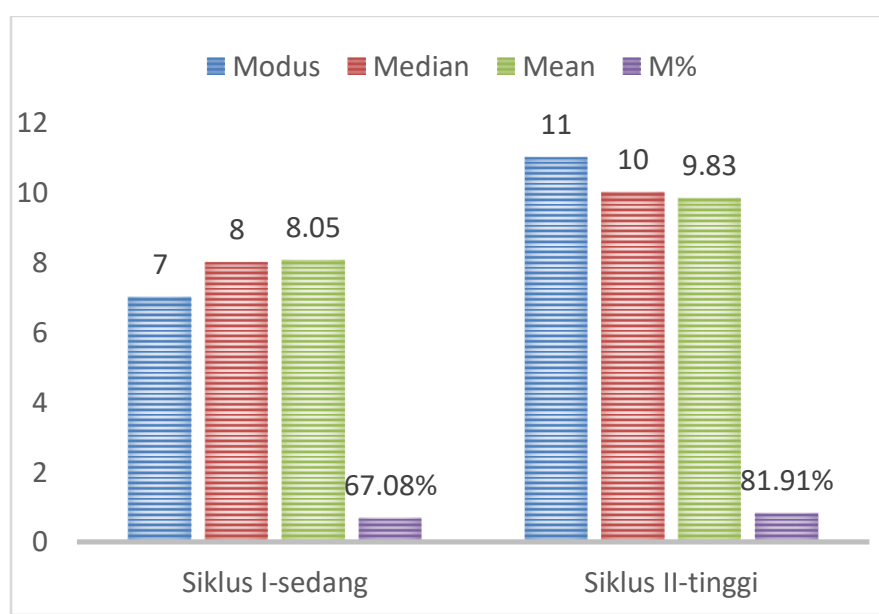

Gambar 4. Gambar Grafik Persentase Peningkatan Kemampuan Berbicara pada Siklus I dan Siklus II

Berdasarkan grafik di atas dapat dijelaskan peningkatan kemampuan berbicara anak pada siklus I dimana modus atau skor frekuensi tertinggi dengan skor 7, median dengan skor 8, mean 8,05 dan hasil M\% dengan nilai 67,08\% bila dikonversikan ke dalam PAP skala lima berada pada tingkat penguasaan 65-79 yang berarti tingkat kemampuan berbicara anak pada siklus I berada pada kriteria sedang. Sedangkan pada siklus II mengalami kenaikan dimana modus atau skor frekuensi tertinggi dengan skor 11, median dengan skor 10, mean 9,83 dan 
hasil M\% dengan nilai $81,91 \%$ bila dikonversikan ke dalam PAP skala lima berada pada tingkat penguasaan 80-89 yang berarti tingkat kemampuan berbicara anak pada siklus II berada pada kriteria tinggi.

Setelah dilaksanakan perbaikan dari proses pembelajaran sikus I, dalam pelaksanaan siklus II terjadi peningkatan yang dapat dilihat pada kemampuan berbicara anak yang sebelumnya berada pada kriteria sedang meningkat menjadi kriteria tinggi.

Adapun temuan-temuan yang diperoleh selama pelaksanaan siklus II yaitu: (a) seluruh anak mampu bekerjasama dengan temannya dan mengikuti setiap langkah penerapan model pembelajaran talking stick dengan baik, (b) banyak anak yang berantusias dalam bercerita dan bekerjasama kelompok, (c) beberapa anak yang bingung sudah mampu bercerita singkat dan tampil lebih berani, dan (d) bimbingan, arahan, dan motivasi tetap diberikan pada anak.

Berdasarkan kenyataan dan bukti di atas, data yang diperoleh selama penelitian berlangsung terkait kemampuan berbicara anak mengalami peningkatan. Dapat disimpulkan bahwa dengan adanya penerapan model pembelajaran talking stick berbantuan media flashcard dapat meningkatan kemampuan berbicara anak. Hasil yang dicapai pada siklus II menjadi dasar bagi peneliti untuk menghentikan penelitian ini hanya sampai pada siklus II karena sudah sesuai dengan hipotesis tindakan dan mencapai indikator keberhasilan yang telah ditentukan.

\section{Pembahasan}

Hasil penelitian menunjukkan bahwa peningkatan kemampuan berbicara pada anak dapat dikatakan sesuai harapan dengan adanya penerapan model pembelajaran talking stick berbantuan media flash card. Terbukti pada saat pelaksanaan siklus I beberapa kemampuan berbicara masih belum optimal dikarenakan anak masih bingung sehingga terlihat malu saat bercerita. Ketika kegiatan dilakukan sebanyak 4 kali pertemuan terbukti dapat meningkatkan kemampuan berbicara anak dengan model pembelajaran talking stick berbatuan media flash card yang menarik bagi anak, selain itu anak dapat menjawab pertanyaan guru dengan memilih sendiri flash card yang disediakan. Sesuai dengan teori yang telah dijelaskan oleh Tilong (2014: 7) disamping sebagai sarana permainan, flash card sekaligus berfungsi sebagai media belajar yan efektif bagi anak, terutama dalam hal menghafal, mengingat, bercerita dan berbicara.

Hasil refleksi siklus I menjadi bahan diskusi antara peneliti dengan guru kelas untuk menggunakan pengalaman langsung pada siklus II, dimana anak diberikan kesempatan untuk memilih sendiri flash card yang ingin digunakan dengan harapan anak akan lebih tertarik dan termotivasi serta mau berbicara di depan kelas dengan kartu pilihannya. Hal ini senada dengan yang dijelaskan Nurbiana Dheni (2005:3.3) dalam berbicara terkadang anak dapat menyesuaikan dengan keinginannya sendiri. Ketika berbicara diperlukan adanya keserasian antara pikiran dan tatanan yang dapat mengekspresikan gagasan yang tertuang dalam kata atau kalimat yang diucapkan anak.

Ketika anak menggunakan model pembelajaran talking stick anak secara langsung akan mengikuti aturan bermain, dimana anak diharapkan dapat bekerjasama dengan kelompok dan menunjukkan sikap berani saat mendapatkan giliran untuk bercerita di depan kelas, yang nantinya sebagai kegiatan untuk dapat meningkatkan kemampuan berbicaranya. Pemberian reward berupa flash card yang dapat anak-anak pilih sendiri digunakan guru untuk membentuk pengalaman baru bagi anak, dimana anak diharapkan agar berlomba-lomba untuk mau berbicara di depan kelas sesuai dengan flash card yang anak miliki.

Berdasarkan hasil penelitian dan pemaparan yang telah dipaparkan sebelumnya, menunjukan bahwa penerapan model pembelajaran talking stick berbantuan media flash card terbukti efektif untuk meningkatan kemampuan berbicara anak kelompok B2 TK Kartika VII-3 Singaraja dibandingkan anak mengikuti pola pembelajaran seperti biasanya.

Ditinjau dari hasil penelitian, terlihat adanya peningkatan kemampuan berbicara anak yang meliputi ketepatan ucapan, pilihan kata, dan kenyaringan suara serta kelancaran dalam berbicara. Menurut peneliti bahwa penelitian ini sudah memenuhi kriteria standar keberhasilan, untuk itu penelitian dianggap sudah berhasil dan dihentikan. 
Sejalan dengan penelitian tersebut didukung pula dengan penelitian relevan yang dilakukan oleh Sukmadiani (2014) dengan menerapkan model pembelajaran talking stick berbantuan media kartu huruf dapat meningkatkan perkembangan bahasa anak kelompok B TK Hindu Udiana Sari Tunjuk. Hasil analisis data menunjukkan bahwa terjadi peningkatan perkembangan bahasa dengan media kartu huruf pada siklus I sebesar $69,37 \%$ yang berada pada kategori sedang dan pada siklus II sebesar 83,06 \% yang berada pada kategori tinggi. Jadi, dapat disimpulkan bahwa terjadi peningkatan perkembangan bahasa sebesar 13,69\%. Keberhasilan lainnya ditunjukkan oleh penelitian yang dilakukan Martha (2015) yang berjudul penerapan model pembelajaran talking stick berbantuan media flip chart untuk meningkatkan kemampuan berbahasa lisan anak kelompok B3 semester II PAUD Kusuma 2 Denpasar, dalam penelitiannya menunjukkan bahwa pada siklus I diperoleh rata-rata yaitu $65.72 \%$ dan siklus II meningkat menjadi $84.27 \%$. Berdasarkan penelitian tersebut maka dapat disimpulkan bahwa terjadi peningkatan kemampuan berbahasa lisan setelah diterapkannya model pembelajaran talking stick berbantuan media flash card.

Berdasarkan penelitian relevan tersebut, memperkuat simpulan penelitian yang telah dilakukan bahwa dengan penerapan model pembelajaran talking stick berbantuan media flash card dapat meningkatan kemampuan berbicara anak kelompok B2 TK Kartika VII-3 Singaraja. Strategi pembelajaran tersebut perlu diterapkan dan juga dapat pula dikembangkan lagi dengan kreatif dan berinovasi sehingga berpotensi baik bagi perkembangan pembelajaran di PAUD.

\section{Simpulan dan Saran}

Berdasarkan hasil analisis data dan pembahasan yang telah diuraikan dapat ditarik simpulan sebagai berikut. Terdapat peningkatan kemampuan berbicara pada anak kelompok B2 TK Kartika VII-3 Singaraja setelah diterapkan model pembelajaran talking stick berbantuan media flashcard mencapai $14,83 \%$. Hal ini terlihat dari peningkatan persentase rata-rata kemampuan berbicara pada siklus I, M\% $=67,08 \%$ yang berada pada kriteria sedang menjadi sebesar $81,91 \%$ pada siklus II yang berada pada kriteria tinggi. Dengan demikian dapat disimpulkan bahwa penerapan model pembelajaran talking stick berbantuan media flashcard dapat meningkatkan kemampuan berbicara anak kelompok B1 TK Kartika VII-3 Singaraja Tahun Pelajaran 2018/2019.

Berdasarkan hasil dan pembahasan dalam penelitian ini, dapat dikemukakan beberapa saran yaitu: (a) bagi guru, disarankan dalam pengembangan kemampuan berbicara anak, hendaknya guru lebih kreatif dan inovatif dalam melaksanakan pembelajaran di dalam kelas dengan anak, khususnya terkait media pembelajaran, inovasi guru dalam mengajar dan kreativitas guru tentang metode pembelajaran. Karena dengan media dan metode yang bervariasi anak leih tertarik dan mau melakukan hal yang diperintahkan oleh guru. Selain itu anak menjadi berani tampil berbicara di depan kelas, (b) bagi peneliti lain, disarankan peneliti berharap pada penelitian yang serupa dengan penelitian yang dilakukan peneliti namun dengan permainan yang lebih inovatif dan kreatif sesuai dengan usia perkembangan anak.

\section{Daftar Pustaka}

Agung, A. A. Gede. 2010. Penelitian Tindakan Kelas (Teori dan Analisis Data dalam PTK). Singaraja: FIP Undiksha.

2012. Metodologi Penelitian Pendidikan. Singaraja: Universitas Pendidikan Ganesha.

Adi D Tilong. 2014. Lebih dari 40 aktivitas perangsang otak kanan dan kiri anak bisa lebih canggih. Jogjakarta. Diva Press.

Dhieni Nurbiana. 2007. Metode Pengembangan Bahasa. Jakarta: Universitas terbuka 
Jurnal Ilmiah Pendidikan Profesi Guru Vol. 2 No. 3, Oktober 2019

P-ISSN : 2621-5713, E-ISSN : 2621-5705

Jasmi. 2014. Tinjauan Pustaka Model Pembelajaran talking Stick. http://digilib.unila.ac.id/500/3/BAB\%20II.pdf (Diadaptasi Tanggal 14 September 2018).

Martha. (2015). penerapan model pembelajaran talking stick berbantuan media flip chart untuk meningkatkan kemampuan berbahasa lisan anak kelompok B3 semester II PAUD Kusuma 2 Denpasar (Tidak Diterbitkan). PG PAUD UPP Denpasar.

Sutan, Firmanawaty. 2004. Mahir Matematika Melalui Permainan. Depok: Puspa Swara.

Sudijono, Anas. 2011. Pengantar Statistik Pendidikan. Jakarta: PT Raja Grafindo Persada.

Sukmadiani, Ni Nyoman Rai. 2014. model pembelajaran talking stick berbantuan media kartu huruf dapat meningkatkan perkembangan bahasa anak kelompok B TK Hindu Udiana Sari Tunjuk (Tidak Diterbitkan). PG PAUD Univeristas Pendidikan Ganesha.

Suharsimi Arikunto. 2015. Manajemen Penelitian. Jakarta: Rineka Cipta.

Uno, Hamzah B. 2012. Belajar dengan Pendekatan PAILKEM. Jakarta: PT Bumi Aksara.

Yulianti Rani. 2014. Permainan yang meningkatkan kecerdasan anak. Jakarta. Niaga Swadaya 